\title{
PENGARUH KUALITAS LAYANAN INTERNET BANKING TERHADAP KEPUASAN NASABAH PADA PT BANK NEGARA INDONESIA PERSERO TBK KC MADIUN
}

\author{
Febri Nur Endah Safitri \\ Pendidikan Ekonomi FKIP UNIVERSITAS PGRI MADIUN \\ febrinesendah02@gmail.com
}

\begin{abstract}
This research has purpose to know the quality of internet banking service in PT BNI Persero Tbk KC Madin, to know customer satisfaction at PT BNI Persero Tbk KC Madiun. In this study the population consists of 512 customers with a sample of 225 clients taken with Incidental sampling technique. Technique of taking data taken by questionnaire, observation and documentation. The analysis was processed with SPSS version 20.0 using simple linear regression with hypothesis test, determination test and $t$ test. The result of the research shows that the result of Simple Linear Regression Test is $Y=12,646+0,635 \mathrm{X}$, constant equal to 12,646 meaning if variable of Quality of Internet Banking Service is fixed then Customer Satisfaction amount is 0,635 so there is influence between Quality of Internet Banking Service to Customer Satisfaction. The result of Coefficient of Determination Adjust (R2) is known 0,377 means 37,7\% Quality of Internet Banking Service influenced by Customer Satisfaction, while the rest 62,3\% Quality of Internet Banking Service influenced by other variable not examined in this research. The result of $t$ test is t_hitung value is 11,697 while t_tabel is 1,651. This means that the value of $[t] \_$count $>$t_table $(11,697>1,651)$. so it can be concluded that Ho is rejected and Ha accepted.
\end{abstract}

Keywords: Quality Of Internet Banking Service, Customer Satisfaction

\begin{abstract}
Abstrak
Penelitian ini mempunyai tujuan untuk mengetahui kualitas layanan internet banking di PT BNI Persero Tbk KC Madin, untuk mengetahui kepuasan nasabah pada PT BNI Persero Tbk KC Madiun. Dalam penelitian ini populasi terdiri dari 512 nasabah dengan sampel sebanyak 225 nasabah diambil dengan teknik sampling Insidental. Teknik pengambilan data diambil dengan angket, observasi dan dokumentasi. Analisa diolah dengan program SPSS versi 20.0 menggunakan regresi linear sederhana dengan uji hipotesis, uji determinasi dan uji t. Hasil Penelitian menunjukkan bahwa hasil dari Uji Regresi Linier Sederhana adalah Y= 12,646 + 0,635 X, konstanta sebesar 12,646 artinya apabila variabel Kualitas Layanan Internet Banking bernilai tetap maka besarnya Kepuasan Nasabah adalah sebesar 0,635 sehingga ada pengaruh antara Kualitas Layanan Internet Banking terhadap Kepuasan Nasabah. Hasil dari Koefisien Determinasi Adjust $\left(K^{2}\right)$ diketahui 0,377 berarti 37,7\% Kualitas Layanan Internet Banking dipengaruhi oleh Kepuasan Nasabah, sedangkan sisanya 62,3\% Kualitas Layanan Internet Banking dipengaruhi oleh variabel-variabel lain yang tidak diteliti dalam penelitian ini. Selanjutnya hasil dari Uji t diperoleh nilai $t_{\text {hat }}$ adalah 11,697 sedangkan $t_{t_{1}} \quad$ sebesar 1,651. sehingga dapat disimpulkan bahwa Ho ditolak dan Ha diterima.
\end{abstract}

Kata Kunci: Kualitas Layanan Internet Banking, Kepuasan Nasabah 


\section{PENDAHULUAN}

Perkembangan pesat dari teknologi internet telah menawarkan berbagai macam kemudahan dalam transaksi bisnis, termasuk di dunia perbankan Indonesia. Pentingnya teknologi Informasi dalam bisnis tidak di ragukan lagi. Banyak perusahaan di dunia berkeinginan untuk mengubah dirinya menjadi pembangkit daya (power house) bisnis global melalui berbagai investasi besar dalam e-bussines, e-commerce, dan usaha Teknologi Informasi yang global.Sehubungan dengan perkembangan teknologi informasi saat ini, telah menciptakan jenis-jenis dan peluangpeluang bisnis yang baru dimana transaksitransaksi bisnis makin banyak dilakukan secara elektronikayang memungkinkan setiap orang dengan mudah melakukan perbuatan hukum seperti misalnya melakukan transaksi jual beli.

Perkembangan internet memang cepat dan memberi pengaruh signifikan dalam berbagai aspek salah satunya adalah dalam dunia perbankan. Kasmir (2002:3) manyatakan bahwa "bank diartikan sebagai lembaga keuangan yang kegiatan usahanya adalah menghimpun dana dari masyarakat dan menyalurkan kembali dana tersebut ke masyarakat serta memberikan jasa-jasa bank lainnya."Salah satu jasa perbankan yang mulai mendapat perhatian adalah Internet Banking. Tujuan utama dari strategi pemasaran yang dijalankan adalah untuk meningkatkan jumlah nasabahnya, baik secara kuantitas maupun kualitas. Secara kuantitas artinya jumlah nasabah bertambah cukup signifikan dari waktu kewaktu, sedangkan secara kualitas artinya nasabah yang didapat merupakan nasabah yang produkif yang mampu memberikan laba bagi bank. Untuk mencapai tujuan tersebut dapat dilakukan dengan berbagai cara dan salah satunya adalah melalui memberikan kepuasan nasabah atau pelanggan (Kasmir, 2008 : 161).

Keberhasilan perusahaan perbankan dalam mempertahankan nasabahnya sangat ditentukan oleh ketepatan strategi yang dipakai yang disesuaikan dengan situasi dan kondisi dari sasaran pasar. Dalam menentukan strategi pemasaran, pihak perbankan perlu mengkaji setiap karakteristik perilaku nasabah, yang diimplementasikan ke dalam harapan dan keinginannya. Dengan mengetahui keinginan nasabah, maka dapat diketahui strategi yang tepat untuk digunakan.

Tujuan utama dari strategi pemasaran yang dijalankan adalah untuk meningkatkan jumlah nasabahnya, baik secara kuantitas maupun kualitas. Secara kuantitas artinya jumlah nasabah bertambah cukup signifikan dari waktu kewaktu, sedangkan secara kualitas artinya nasabah yang didapat merupakan nasabah yang produkif yang mampu memberikan laba bagi bank. Untuk mencapai tujuan tersebut dapat dilakukan dengan berbagai cara dan salah satunya adalah melalui memberikan kepuasan nasabah atau pelanggan.

Penelitian mengenai pengaruh kualitas layanan internet banking terhadap kepuasan nasabah telah banyak dilakukan. Penelitian yang dilakukan Jujuk Herawati dan Prayekti, M.Si (2011) dengan judul Pengaruh Dimensi Internet Banking Service Qualily Dan Kepercayaan Nasabah Terhadap Kepuasan Nasabah (Penelitian Empiris terhadap Nasabah Internet Banking di Kota Yogyakarta). Hasil penelitian menunjukkan terdapat pengaruh positif antara dimensi internet banking service quality (IBSQ) yang meliputi online customer service, Online system information quality, dan banking service product quality serta kepercayaan nasabah terhadap kepuasan nasabah internet banking. 
Selanjutnya di dukung oleh penelitian yang dilakukan oleh Ni Made Savitri Anggaeni \& Ni Nyoman Kerti Yasa (2012) dengan judul E-Service Quality Terhadap Kepuasan dan Loyalitas Pelanggan Dalam Menggunakan Internet Banking. Hasil penelitian menunjukkan $e$ service quality berpengaruh positif dan signifikan terhadap kepuasan pelanggan dalam penggunaan internet banking.

Menurut Rambat Lupiyoadi (2001: 158) Dalam menentukan tingkat kepuasan pelanggan, terdapat lima faktor utama yang harus diperhatikan oleh perusahaan yaitu :

1. Kualitas produk, pelanggan akan merasa puas bila hasil evaluasi mereka menunjukkan bahwa produk yang mereka gunakan berkualitas.

2. Kualitas pelayanan, terutama untuk industri jasa, pelanggan akan merasa puas bila mereka mendapatkan pelayanan yang baik atau yang sesuai dengan yang diharapkan.

3. Emosional, pelanggan akan merasa bangga dan mendapatkan keyakinan bahwa orang lain akan kagum terhadap dia bila menggunakan produk dengan merek tertentu yang cenderung mempunyai tingkat kepuasan yang lebih tinggi.

4. Harga, produk yang mempunyai kualitas yang sama tetapi menetapkan harga yang relati murah akan memberikan nilai yang lebih tinggi kepada pelangganya.

5. Biaya, pelanggan yang tidak perlu mengeluarkan biaya tambahan atau tidak perlu membuang waktu untuk mendapatkan suatu produk atau jasa cenderung puas terhadap produk atau jasa itu.

Menurut M. Nur Rianto (2012: 213) Service Quality adalah "perbandingan antara kenyataan dan harapan pelanggan atau nasabah, jika kenyataan yang diterima lebih dari yang diharapkan, maka layanan dapat diaktakan bermutu dan nasabah akan puas, sebaliknya jika kenyataan kurang dari yang diharapakan, maka layanan dikatakan tidak bermutu".

Menurut Gronroos dalam Christopher Lovelock (2010: 154) bahwa kualitas yang dirasakan dari pelayanan adalah hasil dari suatu proses evaluasi dimana pelanggan membandingkan persepsi mereka terhadap pelayanan dan hasilnya, dengan apa yang mereka harapkan.

Budi Agus Riswandi (2003:76) menyatakan pada dasarnya "internet banking memiliki tiga tahap pelayanan yang ditawarkan kepada nasabahnya, yaitu pertama: layanan informasi (information) dimana bank hanya menyediakan informasi jasa keuangan dalam website nya; kedua: komunikasi (communication) dimana dalam website tersebut juga memungkinkan nasabah untuk dapat berkomunikasi dengan baik; ketiga: transaksi (transactional/advance) dimana sudah memungkinkan nasabah untuk melakukan transaksi-transaksi keuangan virtual seperti transfer dana, pengecekan saldo ataupun berbagai jenis pembayaran."

Menurut Rod et al. (2009) dalam Jajuk (2011:6-7) dimensi dari kualitas layanan internet banking adalah :

1. Online customer service quality memiliki indikator-indikator : tangible, reliability, responsiveness, emphaty, assurance

2. Online system information quality memiliki indikator-indikator : ease to use, accuracy, security/privacy, contens, timeless, aesthetic.

\section{Banking service product quality}

Menurut Anderson (1994) dalam Lina Anatan (2008: 70) menunjukkan "adanya hubungan antara kualitas pelayanan dengan kepuasan pelanggan. Ia menyatakan bahwa 
perbaikan kualitas pelayanan akan menghasilkan kepuasan nasabah, oleh karena itu hubungan tersebut harus ditingkatkan".

Hal ini didukung oleh Zeithaml (1994) dalam Lina Anatan (2008: 70) yang menyatakan adanya hubungan yang kuat dengan nasabah ketika nasabah memberikan penilaian positif tentang kualitas pelayanan dan hubungan yang lemah ketika nasabah membuat penilaian negative tentang kualitas pelayanan perusahaan.

Penelitian mengenai pengaruh kualitas layanan internet banking terhadap kepuasan nasabah telah banyak dilakukan. Penelitian yang dilakukan Jujuk Herawati dan Prayekti, M.Si (2011) dengan judul Pengaruh Dimensi Internet Banking Service Qualily Dan Kepercayaan Nasabah Terhadap Kepuasan Nasabah (Penelitian Empiris terhadap Nasabah Internet Banking di Kota Yogyakarta). Perbedaan penelitian yang dibandingkan oleh peneliti, dalam penelitian yang telah dilakukan oleh Jajuk Herawati dan Prayekti menggunakan metode deskriptif dan metode inferensial, sedangkan dalam penelitian ini menggunakan metode insidental dengan teknik non probability sampling.

Persamaan penelitian yang relevan di atas dengan penelitian peneliti yaitu sebagai berikut: variabel kualitas layanan internet banking memiliki pengaruh signifikan terhadap kepuasan nasabah.

Selanjutnya di dukung oleh penelitian yang dilakukan oleh Ni Made Savitri Anggaeni \& Ni Nyoman Kerti Yasa (2012) dengan judul E-Service Quality Terhadap Kepuasan dan Loyalitas Pelanggan Dalam Menggunakan Internet Banking.

Perbedaan penelitian yang dibandingkan oleh peneliti, dalam penelitian yang telah dilakukan oleh Ni Made Savitri
Anggaeni \& Ni Nyoman Kerti Yasa (2012) pengambilan sampel menggunakan purposive sampling, sedangkan dalam penelitian ini menggunakan metode insidental dengan teknik non probability sampling.

Persamaan penelitian menunjukkan e-service quality berpengaruh positif dan signifikan terhadap kepuasan pelanggan dalam penggunaan internet banking.

Kepuasan pelanggan terjadi setelah seorang pelanggan melakukan pembelian terhadap suatu barang atau jasa. Setelah adanya pembelian dan menggunakan produk atau jasa, seorang pelanggan melakukan evaluasi terhadap pelayanan yang diberikan. Seorang pelanggan merasa puas terhadap suatu produk barang atau jasa apabila pelayanan yang diberikan oleh suatu perusahaan sesuai dengan harapan dan keinginan pelangganya. Pelayanan dikatakan berkualitas apabila jasa atau pelayanan yang diterima pelanggan melebihi harapannya. Kualitas pelayanan dapat diketahui dengan cara membandingkan harapan dari para pelanggan atas pelayanan yang nyata diperoleh pelanggan dengan pelayanan yang mereka harapkan.

Usaha yang bergerak dalam bidang jasa, dalam menjalankan usahanya harus memperhatikan kualitas layanan internet banking yang disediakan.. Kualitas layanan internet banking pada PT BNI Persero Tbk KC Madiun mempunyai peran yang sangat penting. Dengan adanya kualitas layanan internet banking yang baik, maka harapan dan keinginan nasabah bisa terpenuhi, sehingga para nasabah merasa puas.

\section{METODE PENELITIAN}

Penelitian dilaksanakan di PT. BNI Persero Tbk KC Madiun. Alasan pemilihan tempat tersebut dikarenakan PT BNI Persero Tbk KC Madiun merupakan salah 
satu Bank BUMN yang terdapat di Kota Madiun yang menyediakan fasilitas layanan internet banking, sehingga dapat dilakukan penelitian bagi para nasabah yang merasa puas dengan jasa layanan internet banking yang terdapat di PT BNI tersebut.

Desain penelitian yang digunakan dalam penelitian ini menggunakan hubungan sebab akibat (kausal). "Penelitian kuantitatif metode penelitian yang berlandaskan pada filsafat positivisme, digunakan untuk meneliti pada populasi atau sampel tertentu, pengumpulan data menggunakan instrument penelitian, analisis data bersifat kuantitatif atau statistik, dengan tujuan untuk menguji hipotesis yang telah ditetapkan" (Sugiyono, 2006: 14).

Populasi dalam penelitian ini adalah seluruh nasabah pada PT. BNI Persero Tbk KC Madiun yang menggunakan jasa layanan internet banking sebanyak 512 nasabah. Sedangkan Sampel yang digunakan dalam penelitian ini sejumlah 225 nasabah.

Pengambilan sampel dilakukan dengan teknik Sampling Insidental. Teknik pengumpulan data yang digunakan adalah : 1. Angket

Dalam mengambil data variabel Kualitas Layanan Internet Banking (X) dan variabel Kepuasan Nasabah. Jumlah soal dalam angket ini adalah 20 soal pernyataan, yang terbagi dalam dua variabel yang akan diteliti. 10 soal untuk variabel Kualitas Layanan Internet Banking (X) dan 10 soal untuk variabel Kepuasan Nasabah (Y). Yang menjadi responden dalam teknik pengumpulan data dengan angket pada penelitian ini adalah nasabah "PT. BNI Persero Tbk KC Madiun” sebanyak 225 nasabah.
2. Observasi

Dalam penelitian ini metode observasi dilakukan dengan cara peninjauan secara langsung ke objek penelitian yaitu PT. BNI Persero Tbk KC Madiun untuk memperoleh data yang diperlukan guna kelancaran penyusunan penelitian yang berkaitan dengan judul yang di teliti.

3. Dokumentasi

Metode ini digunakan untuk memperoleh data-data yang peneliti butuhkan dengan melalui catatancatatan yang ada atau dokumendokumen yang ada berupa foto dari karyawan dalam melayani nasabahnya.

1. Uji Prasarat atau Instrumen

a. Uji Validitas

Dalam uji validitas digunakan korelasi product moment.

b. Uji Reliabilitas

Uji reliabilitas yang digunakan dalam penelitian ini menggunakan metode Alpha Cronbach.

Menurut Syofiyan Siregar (2014:89) Alpha Cronbach adalah "metode yang digunakan untuk menghitung reabilitas suatu tes yang tidak mempunyai pilihan "benar" atau "salah" maupun "ya" atau "tidak", melainkan digunakan untuk menghitung reabilitas suatu tes yang mengukur sikap atau perilaku".

2. Uji Asumsi Klasik

Menurut Imam Gunawan (2016: 92) Uji Asumsi Klasik merupakan "uji data yang digunakan untuk mengetahui apakah data penelitian memenuhi syarat untuk dianalisis lebih lanjut, guna menjawab hipotesis penelitian". Uji Asumsi Klasik dalam penelitian ini menggunakan Uji Normalitas.

Menurut Sudarmanto 2005 dalam buku Imam Gunawan (2016: 93) Uji 
normalitas dapat dilakukan dengan berbagai cara, salah satunya adalah uji Kolmogorov Smirnov. Uji normalitas dilakukan dengan uji nilai Kolmogorov Smirnov dapat menggunakan program analisis statistik IBM SPSS Statistics 20. Apabila nilai probabilitas $\geq 0,05$ maka data dinyatakan berdistribusi normal, sebaliknya jika nilai probabilitas < 0,05 maka data dinyatakan berdistribusi tidak normal.

3. Uji Hipotesis atau Analisis Data

Untuk uji hipotesis menggunakan teknik analisis regresi linier sederhana menggunakan koefisien determinan dan uji t. Koefisien determinasi digunakan untuk menguji pengaruh antara variabel satu dengan yang lain. Variabel yang dimaksud adalah variabel independen yaitu Kualitas Layanan Internet Banking (X) dan variabel dependen yaitu Kepuasan Nasabah (Y). Sedangkan uji $\mathrm{t}$ untuk mengetahui apakah variabel bebas secara individu mempunyai pengaruh yang signifikan terhadap variabel terikat.

\section{HASIL DAN PEMBAHASAN}

Dideskripsikan bahwa Kualitas Layanan Internet Banking dengan jumlah data (N) sebanyak 225 responden mempunyai deskripsi data sebagai berikut: (a) Jumlah skor total sebesar 8433; (b) Nilai rata-rata hitung (mean) sebesar 37,48; (c) Median sebesar 38,00; (d) Modus sebesar 35; (e) Standar deviasi sebesar 5,148; (f) Nilai minimum sebesar 25; (g) Nilai maximum sebesar 47.

Hasil analisis deskriptif Kualitas Layanan Internet Banking yang diolah dari 225 responden yang menyatakan sebanyak 116 nasabah atau 51,5\% di atas rata-rata dan sebanyak 109 nasabah atau 48,4\% di bawah rata-rata. Dengan demikian Kualitas
Layanan Internet Banking pada PT BNI Persero Tbk KC Madiun cukup baik.

Dideskripsikan bahwa Kepuasan Nasabah dengan jumlah data $(\mathrm{N})$ sebanyak 225 responden mempunyai deskripsi data sebagai berikut: (a) Jumlah skor total sebesar 8204; (b) Nilai rata-rata hitung (mean) sebesar 36,46; (c) Median sebesar 37,00; (d) Modus sebesar 42; (e) Standar deviasi sebesar 5,305; (f) Nilai minimum sebesar 22; (g) Nilai maximum sebesar 47.

Hasil analisis deskriptif Kepuasan Nasabah yang diolah dari 225 responden yang menyatakan sebanyak 115 nasabah atau $51,1 \%$ di atas rata-rata dan sebanyak 110 nasabah atau 48,8\% di bawah ratarata. Dengan demikian Kepuasan Nasabah yang diterapkan di PT. BNI Persero Tbk KC Madiun cukup baik.

\section{Hasil Uji Validitas}

Hasil dari uji validitas angket Kualitas Layanan Internet Banking di uji kepada nasabah di PT. BNI Persero Tbk KC Madiun berjumlah 20 responden. Dari 10 soal Kepuasan Nasabah yang di uji hasilnya semua valid. Hasil dari uji validitas angket Kepuasan Nasabah di uji kepada nasabah di PT. BNI Persero Tbk KC Madiun berjumlah 20 responden. Dari 10 soal Kepuasan Nasabah yang di uji hasilnya semua valid (koefisien di atas 0,4227) dapat dipergunakan oleh peneliti sebagai instrumen penelitian.

\section{Hasil Uji Reliabilitas}

Uji Reliabilitas pada penelitian ini dilakukan dengan menggunakan rumus alpha cronbach. Syofian Siregar (2014: 90), "kriteria suatu instrumen penelitian dikatakan reliabel dengan menggunakan teknik Alpha Cronbach bila koefisien reliabilitas $\left(r_{11}\right)>0,6 "$. Hasil uji reliabilitas variabel Kualitas Layanan 
Internet Banking dan Kepuasan Nasabah adalah 0,839 dan 0,883 maka semua dinyatakan reliabel.

\section{Hasil Uji Asumsi Klasik}

Uji Normalitas bertujuan untuk menguji apakah dalam model regresi variabel pengganggu atau residu memiliki distribusi normal. Apabila data berdistribusi normal, maka dapat digunakan uji statistik berjenis parametrik. Syarat analisis parametrik yaitu distribusi data harus normal. Pengujian menggunakan uji Kolmogorov-Smirnov (Analisis Explore) untuk mengetahui apakah distribusi data pada tiap-tiap variabel normal atau tidak. Hasil uji normalitas yang terdapat di atas bahwa nilai Assymp Sig sebesar 0.750 lebih besar dari 0.05, dengan demikian dapat disimpulkan bahwa data yang akan dianalisis terdistribusi normal.

\section{Uji Regresi Linier Sederhana}

Uji Regresi Linier sederhana diperoleh persamaan $\mathrm{Y}=12,646+0,635 \mathrm{X}$. Konstanta sama dengan 12,646, artinya apabila variabel Kualitas Layanan Internet Banking bernilai tetap atau konstant, maka besarnya Kepuasan Nasabah adalah 12,646 .

\section{Koefisien Determinasi (Adjust R-Square)}

Dari hasil pengolahan data dengan menggunakan program SPSS versi 20.0 dapat diketahui bahwa koefisien determinasi (Adjust R-Square) yang diperoleh sebesar 0,377. Yang artinya, Kualitas Layanan Internet Banking berpengaruh terhadap Kepuasan Nasabah pada PT. BNI Persero Tbk KC Madiun sebesar 37,7\% sedangkan sisanya sebesar $62,3 \%$ dipengaruhi oleh faktor lain yang tidak diteliti.

\section{Uji T}

Dari hasil perhitungan uji t diperoleh nilai uji $\mathrm{t}$ diperoleh nilai $\mathrm{t}_{\text {hitung }}$ sebesar 11,697 sedangkan $t_{\text {tabel }} 1,651$, dilain pihak nilai $\mathrm{Sig}_{\text {hit }}$ adalah 0,000 sedangkan Sig prob 0,05 . Hal ini berarti bahwa nilai $t_{\text {hitung }} \geq$ $\mathrm{t}_{\text {tabel }}(11,697 \geq 1,651)$ atau $\mathrm{Sig}$ hit $\leq \mathrm{Sig}_{\text {prob }}$ $(0,000 \leq 0,05)$. Atas dasar uji t tersebut dapat disimpulkan bahwa $\mathrm{H}_{0}$ ditolak dan Ha diterima,yang berarti ada pengaruh antara kualitas layanan internet banking terhadap kepuasan nasabah pada PT BNI Persero Tbk KC Madiun.

\section{PENUTUP \\ Simpulan}

Berdasarkan hasil analisis data dan pembahasan yang telah dilakukan pada bab sebelumnya, maka dapat disimpulkan sebagai berikut :

1. Kualitas Layanan Internet Banking Pada PT BNI Persero Tbk KC Madiun cukup baik. Dari hasil penelitian tersebut dihasilkan nilai rata-rata sebanyak 37,48. Sehingga diperoleh nilai yang berada di atas rata-rata sebanyak 116 nasabah atau sebesar 51,5\%, sedangkan yang dibawah rata-rata sebanyak 109 atau sebesar $48,4 \%$.

2. Kepuasan Nasabah pada PT BNI Persero Tbk KC Madiun cukup baik. Dari hasil penelitian tersebut dihasilkan nilai rata-rata sebanyak 36,46 . Sehingga diperoleh nilai yang berada di atas ratarata sebanyak 115 nasabah atau sebesar $51,1 \%$, sedangkan yang berada di bawah rata-rata sebanyak 110 nasabah atau sebesar $48,8 \%$.

3. Kualitas layanan internet banking mempunyai pengaruh terhadap $\mathrm{Ke}$ puasan nasabah pada PT BNI Persero Tbk KC Madiun, terbukti dari hasil analisis melalui : 
a. Uji Regresi Linier Sederhana. Dari hasil uji regresi linier sederhana di peroleh $\mathrm{Y}$ $=12,646+0,635 \mathrm{X}$ yang artinya konstanta sama dengan 12,646, artinya apabila variabel Kualitas Layanan Internet Banking tetap atau constant, maka besarnya Kepuasan Nasabah adalah 12,646. Sehingga ada pengaruh yang signifikan antara Kualitas Layanan Internet Banking terhadap Kepuasan Nasabah.

b. Koefisien Determinasi yang digunakan untuk mengetahui seberapa besar prosentase Kualitas Layanan Internet Banking terhadap Kepuasan Nasabah. Diketahui Adjusted R Square adalah 0,377. Artinya pengaruh dari Kualitas Layanan Internet Banking terhadap Kepuasan Nasabah pada PT BNI Persero Tbk KC Madiun yaitu 37,7\% sedangkan sisanya $62,3 \%$ dipengaruhi oleh faktor lain.

c. Uji $t$ diperoleh nilai $t_{\text {hitung }}$ sebesar 11,697 sedangkan $t_{\text {tabel }} 1,651$, dilain pihak nilai Sighitadalah 0,000 sedangkan Sig $_{\text {prob }}$ 0,05 . Hal ini berarti bahwa nilai $t_{\text {hitung }}$ $\geq \mathrm{t}_{\text {tabel }}(11,697 \geq 1,651)$ atau $\mathrm{Sig}_{\text {hit }}$ $\leq \operatorname{Sig}_{\text {prob }}(0,000 \leq 0,05)$. Atas dasar uji $\mathrm{t}$ tersebut dapat disimpulkan bahwa $\mathrm{H}_{0}$ ditolak dan $\mathrm{Ha}$ diterima,yang berarti ada pengaruh antara kualitas layanan internet banking terhadap kepuasan nasabah pada PT BNI Persero Tbk KC Madiun.

\section{Saran}

Berdasarkan kesimpulan yang diperoleh di dalam penelitian, maka peneliti mengajukan saran kepada PT. Bank Jateng KCP Cepu dan bagi Peneliti selanjutnya sebagai berikut :

1. Bagi PT BNI Persero Tbk KC Madiun Diharapkan PT BNI Persero Tbk KC Madiun dapat mempertahankan Kua- litas Layanan Internet Banking. Karena Kualitas Layanan Internet Banking merupakan salah satu upaya untuk meningkatkan jumlah nasabah dalam menggunakan jasa layanannya. Yaitu dengan cara sebagai berikut :

a. menambah fitur-fitur layanan pada aplikasi internet banking BNI yang selama ini belum disediakan,

b. lebih memperkuat jaringan internet untuk memimimalisir gangguan pada saat transaksi,

c. sering melakukan upgrade dan mendesain tampilan aplikasi internet banking agar nasabah tidak bosan dengan tampilan yang sudah pernah dilihat.

d. BNI harus lebih meningkatkan keamanan guna mendapatkan kepercayaan nasabah dalam melakukan transaksi elektronik menggunakan internet banking caranya yaitu dengan melakukan evaluasi dalam jangka waktu tertentu. Dimana tujuan evaluasi ini adalah untuk menganalisa bagaimana kualitas layanan internet banking dari segi keamanan transaksi yang telah diberikan kepada nasabah.

2. Bagi Nasabah

Nasabah yang menggunakan jasa layanan internet banking diharapkan dapat memanfaatkannya dengan bijak dalam menggunakan layanan internet banking BNI. Yaitu dengan cara saat menggunakan internet banking harus tetap berhati-hati, jangan sampai manfaat dari internet banking diambil oleh orang lain, seperti tindak kejahatan. Selain itu dengan cara meningkatkan kesadaran akan teknologi harus selalu ditingkatkan, agar tidak terjadi penipuan.

3. Bagi Peneliti Selanjutnya 
Diharapkan untuk penelitian selanjutnya mampu menerapkan ilmu yang didapatkan dalam penelitian dan peneliti dapat menambah variabel bebas $(\mathrm{X})$, karena selain kualitas layanan Internet Banking masih banyak faktor-faktor lain yang dapat mempengaruhi kepuasan nasabah pada PT BNI Persero Tbk KC Madiun.

4. Bagi Lembaga Universitas PGRI MADIUN

Dengan penelitian ini diharapkan dapat memperoleh wawasan dan pengetahuan yang luas serta dapat dijadikan bahan referensi bagi peneliti selanjutnya di perpustakaan.

\section{DAFTAR PUSTAKA}

Anatan, Lina. 2008. Service Excellence : Competing Through Competitiveness. Bandung : Alfabeta

Jajuk Herawati \& Prayekti. 2011. Pengaruh Dimensi Internet Banking Service Quality Dan Kepercayaan Nasabah Terhadap Kepuasan Nasabah (Penelitian Empiris terhadap Nasabah Internet Banking di Kota Yogyakarta). (http://download.portalgaruda.org/art icle. $p h p ?$ article $=115139 \& v a l=5259$, Diunduh 21 Maret 2017)

Kasmir. 2008. Pemasaran Bank. Jakarta : Kencana
Lovelock, Christopher. 2010. Pemasaran Jasa. Edisi Ketujuh, Jilid 2. Alih Bahasa: Dian Wulandari \& Devri Barnadi Putera. Jakarta : Erlangga

Ni Made Savitri Anggaeni \& Ni Nyoman Kerti Yasa.2012. E-Service Quality Terhadap Kepuasan dan Loyalitas Pelanggan Dalam Menggunakan Internet Banking. (http://e-journal. economicbanking.php?1893647,

(Diunduh 18 Maret 2017)

Nur Rianto, M. 2012. Dasar-Dasar Pemasaran Bank Syariah. Bandung : Alfabeta

Riswandi, Budi, Agus. 2013. Hukum dan Internet di Indonesia. Yogyakarta (anggota IKAPI)

Sugiyono. 2006. Metode Penelitian Pendidikan (Pendekatan Kuantitatif Kualitatif dan $R \& D$. Bandung : Alfabeta

Sugiyono. 2010. Metode Penelitian Pendidikan (Pendekatan Kuantitatif Kualitatif dan $R \& D)$ ). Bandung : Alfabeta

Tjiptono, Fandy \& Gregorius Chandra. 2011. Service, Quality \& Satisfaction. Edisi Ketiga. Yogyakarta : Andi

Tjiptono, Fandy. 2006. Pemasaran Jasa. Malang : Bayumedia Publishing 